University of Nebraska - Lincoln

DigitalCommons@University of Nebraska - Lincoln

January 2002

\title{
A New Species of Hybochaetodus Arrow (Coleoptera: Scarabaeoidea: Hybosoridae: Anaidini) From Peru
}

Federico C. Ocampo

University of Nebraska - Lincoln, focampo2@unl.edu

Follow this and additional works at: https://digitalcommons.unl.edu/entomologypapers

Part of the Entomology Commons

Ocampo, Federico C., "A New Species of Hybochaetodus Arrow (Coleoptera: Scarabaeoidea: Hybosoridae: Anaidini) From Peru" (2002). Papers in Entomology. 124.

https://digitalcommons.unl.edu/entomologypapers/124

This Article is brought to you for free and open access by the Museum, University of Nebraska State at DigitalCommons@University of Nebraska - Lincoln. It has been accepted for inclusion in Papers in Entomology by an authorized administrator of DigitalCommons@University of Nebraska - Lincoln. 


\title{
A New Species of Hybochaetodus Arrow \\ (Coleoptera: Scarabaeoidea: Hybosoridae: Anaidini) from Peru
}

\author{
FEDERICO C. OCAMPO \\ Systematics Research Collections, W 436 Nebraska Hall, \\ University of Nebraska State Museum, \\ Lincoln, NE 68588-0546, U.S.A. \\ focampo@unlserve.unl.edu
}

\begin{abstract}
Hybochaetodus flaco Ocampo, new species, from Cusco, Peru is described and illustrated. The genus Hybochaetodus now includes two species, H. flaco and H. obscurus Arrow, both from Peru. The two species are compared and a diagnosis for the genus Hybochaetodus Arrow is provided.
\end{abstract}

\section{Resúmen}

Se describe e ilustra Hybochaetodus flaco Ocampo, especie nueva, de Cusco, Peru. El género Hybosorus ahora incluye dos especies H. flaco y H. obscurus, ambas de Perú. Se compara las dos especies y se provee una diagnosis del genero Hybochaetodus.

The genus Hybochaetodus was described by Arrow (Arrow 1909), who included only one species, $H$. obscurus Arrow, from Peru. Since its description, the genus has been known only from its type species. With the inclusion of the species I describe herein, the genus includes two species that are endemic to Peru. Little is known of the biology of the species in the genus Hybochaetodus. Species are found at high elevations (about 3,000 m) in the Peruvian Andes. The species described here was collected from dung. This work is a result of my ongoing research on the phylogeny, biogeography, and taxonomy of the family Hybosoridae. In a preliminary phylogenetic analysis based on morphological data (F. C. Ocampo unpubl. data), Hybochaetodus was included in a clade with Anaides Westwood, Chaetodus Westwood (both placed in the tribe Anaidini), and Cryptogenius Westwood and Callosides Howden (both placed in the tribe Cryptogeniini). Based on this preliminary phylogenetic analysis and morphological characters with the Anaidini genera listed above, I place Hybochaetodus in the tribe Anaidini.

\section{Materials and Methods}

Body measurements, puncture density, puncture size, and density of setae are based on the following standards. Body length was measured from the apex of the pronotum (at the middle) to the apex of the elytra. Body width was measured across the elytral humeri. Puncture density was considered "dense" if punctures were nearly confluent to less than two puncture diameters apart, "moderately dense" if punctures were two to six diameters apart, and "sparse" if punctures were separated by more than six diameters. Puncture size was defined as "small" if punctures were $0.02 \mathrm{~mm}$ or smaller, "moderate" if $0.02-0.07 \mathrm{~mm}$, and "large" if $0.07 \mathrm{~mm}$ or larger. Setae were defined as "sparse" if there were few setae, "moderately dense" if the surface was visible but with many setae, and "dense" if the surface was not visible through the setae. Elytral carinae were counted from the elytral suture. Specimen label was copied literally using " "/" between lines of the labels. 


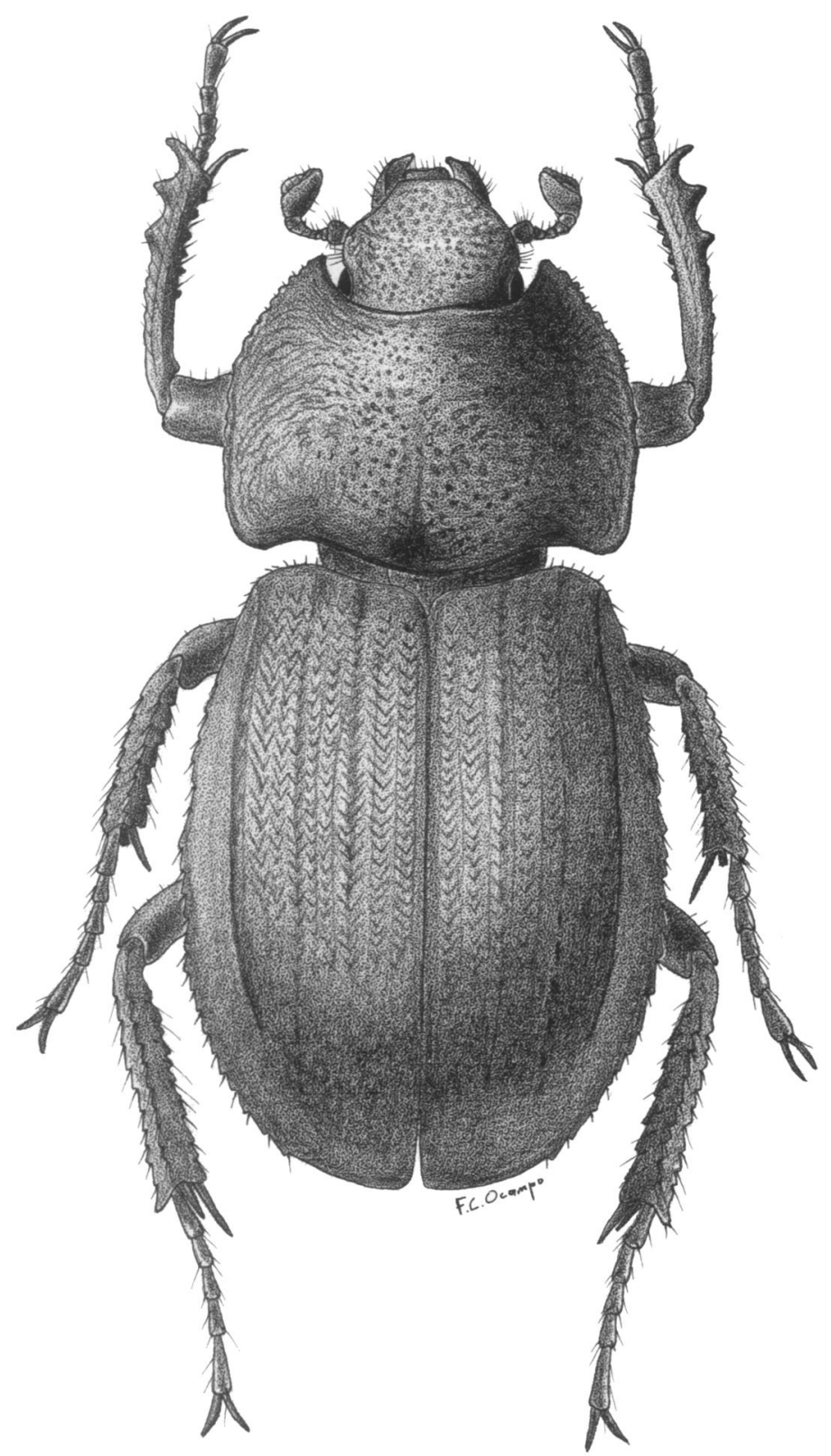

Fig. 1. Habitus of Hybochaetodus flaco Ocampo, new species, from Peru. 

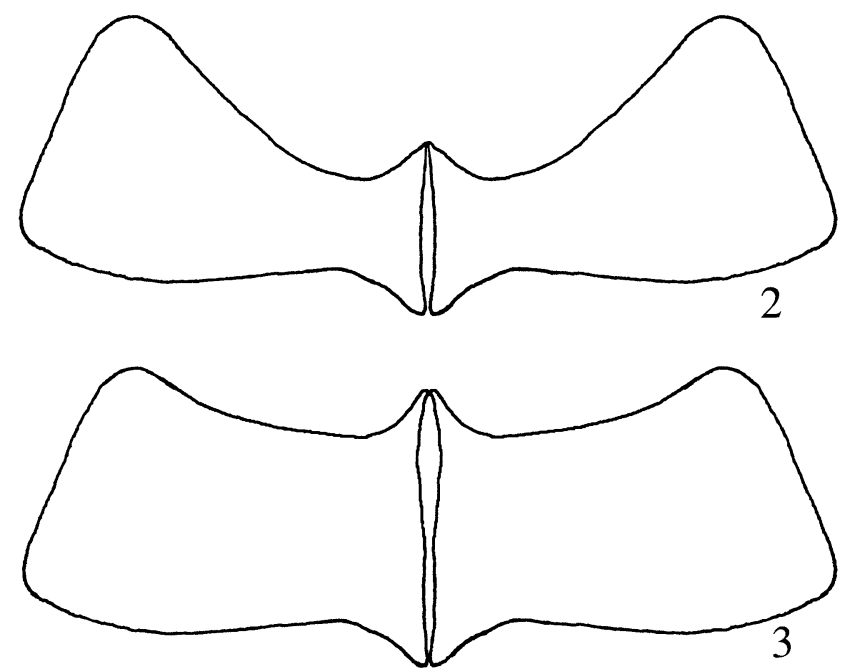

Figs. 2, 3. Metasterna. 2) Hybochaetodus; 3) Anaides.

\section{Hybochaetodus Arrow 1909}

Type species: Hybochaetodus obscurus Arrow 1909:500.

Diagnosis. This genus is distinguished from other genera of Hybosoridae in the New World by the following combination of characters: Pronotum with basiomedial fovea, lacking dorsal carinae (Fig. 1); elytra convex; metasternum short at middle (Fig. 2) versus long at middle as in Anaides (Fig. 3); and meso- and metatibiae lacking transverse carinae.

\section{Hybochaetodus flaco Ocampo, new species}

Figs. 1, 2, 4, 5

Type Material. Holotype male labeled: "Peru: Cusco: Esperanza $/ 13^{\circ} 10^{\prime} 39^{\prime} \mathrm{S}$ $71^{\circ} 36^{\prime} 15^{\prime \prime} \mathrm{W} /$ Elfin forest, $c a$. 2,900 m/pitfall human dung/T. Larsen, XI-10-11, 1999;" my red holotype label: "Hybochaetodus flaco/HOLOTYPE/F. C. Ocampo." Genitalia in glycerin-filled vial beneath specimen. Holotype deposited in the United States National Museum, Washington D.C. (USNM).

Holotype. Male. Length $9.00 \mathrm{~mm}$; width $4.37 \mathrm{~mm}$. Color: Reddish-brown. Head: Frons in dorsal view with base slightly concave in middle; surface punctate in middle, rugose on sides. Frontoclypeal suture obsolete. Clypeal shape subtrapezoidal, apex weakly rounded, surface punctate; punctures moderately dense, large. Clypeal margins not reflexed, vertical surface of apex blunt. Labrum rounded, apex slightly indented; dorsal surface with fringe of setae; lateral margins rounded. Mandibles protruding beyond labrum; external surface sculptured, sparsely setose; apex acute, slightly reflexed; scissorial area with small, preapical tooth. Labium with apex of mentum slightly indented, surface sparsely setose. Antennal club with basal segment cupuliform, capable of receiving penultimate and ultimate segments. Pronotum: Surface convex, 0.7 times as long as wide, surface punctate in middle, rugose on sides; punctures moderately dense (Fig. 1). Base with fovea in middle. Anterior margin with weak bead; lateral margins arcuate, weakly denticulate at apex; posterior margin sinuous. Anterior angles acute; posterior angles nearly right-angled. Scutellum: Shape triangular, surface moderately setose, apex acute. Ely- 

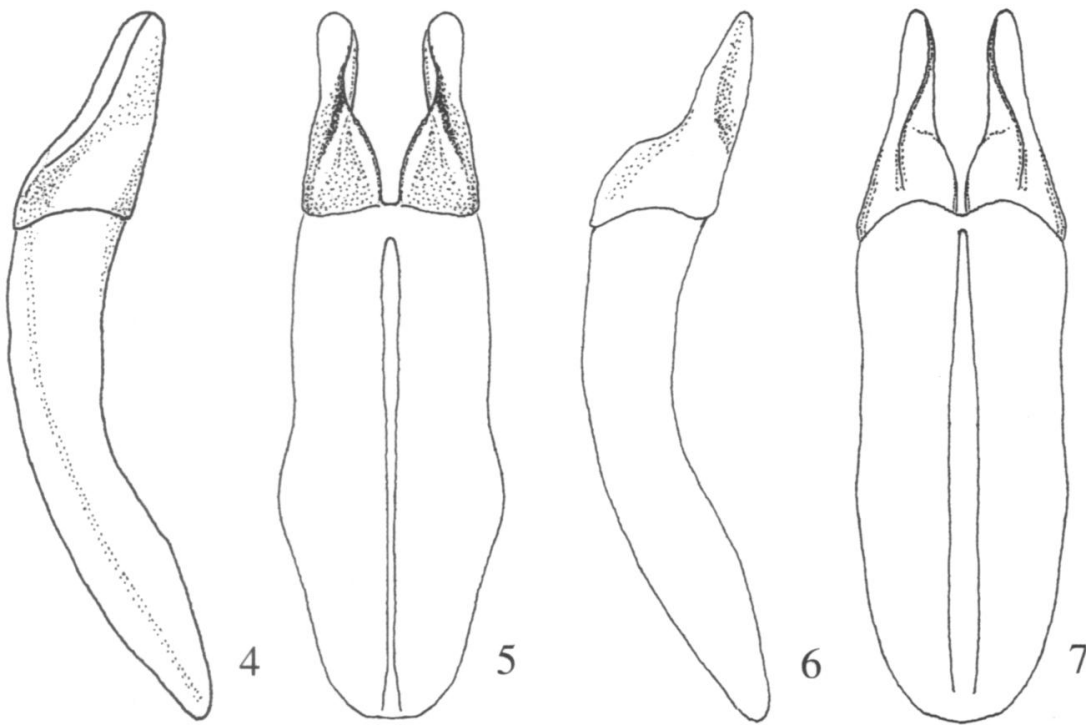

Figs. 4-7. Male parameres and phallobase. 4, 5) Hybochaetodus flaco; 6, 7) H. obscurus; $(4,6)$ lateral and $(5,7)$ ventral views.

tron: Elongated, apex weakly acute; surface with 12 striae; interval with v-shaped surface (Fig. 1); intervals 4 and 7 slightly carinate. Disc with 1 lateral, longitudinal carina; carina extends from humerus to declivous area. Lateral margin weakly denticulate. Epipleuron shagreened, equal in width from humeral angle to $2 / 3$ length, apex tapered. Hind wing: Reduced, obsolete. Venter: Prostemal surface transversely strigulate; prosternal shield with posteriomedial process poorly developed. Meso- and metastemal surface strigulate. Proepisternal surface strigulate. Abdominal sternites transversely strigulate. Legs: Procoxal surface strigulate. Metatrochanter with posteriomedial tooth absent. Femoral surface vermiculate to strigulate, sparsely setose. Protibia with 3 teeth and small denticles on outer margin; basal and middle teeth subtriangular; dorsal surface with 2 setose, longitudinal carinae; protibial spur as long as apical tooth, curved at apex, apex acute. Pro-, meso-, and metatarsomeres 1 longer than 2 and protarsomere 1 with small ventral tooth; tarsomeres 2-4 subequal in length; tarsomere 5 longer than 4. Pro-, meso-, and metatarsal claws shorter than tarsomeres 5, simple, curved. Meso- and metatibiae slender, outer surface with 2 longitudinal rows of teeth, teeth small, 1 seta at base of each tooth. Meso- and metatibial apex with 1 poorly developed spine on outer margin. Mesoand metatibial medial spur longer than external spur, mesotibial external spur with apex blunt, medial spur with apex acuminate. Parameres: (Figs. 4-5).

Diagnosis. This species is distinguished from $H$. obscurus Arrow by the presence of the elytral carina and by the nearly right-angled pronotal posterior angles (Fig. 1), ( $H$. obscurus lacks elytral carinae and its posterior angles are rounded). The shape of the parameres is also diagnostic (Figs. 4-7).

Distribution. Cusco, Peru.

Etymology. From the Spanish flaco, meaning slender; in reference to the narrow body form of this species.

Remarks. The biology of this species is unknown. The specimen on which this description is based was collected at a pitfall trap baited with human dung. Label 
data indicate that the specimen was found in elfin forest at $2,900 \mathrm{~m}$ elevation. Hybochaetodus flaco is only known from the type locality where it occurs in sympatry with $H$. obscurus.

\section{Acknowledgments}

I acknowledge the generous assistance of Brett Ratcliffe, Mary Liz Jameson, and Andrew Smith (all University of Nebraska State Museum) for their critical review of the manuscript. This project was supported by an NSF/PEET grant (DEB9712447) to Brett Ratcliffe and Mary Liz Jameson and by a NSF Biotic Surveys and Inventory grant (DEB 9870202) to Brett Ratcliffe.

\section{Literature Cited}

Arrow, G. 1909. On the characters and relationships of the less known groups of lamellicorn Coleoptera, with descriptions of new species of Hybosoridae, etc. Transactions of the Entomological Society of London 57:479-507.

(Received 23 May 2002; accepted 11 June 2002. Full page charges borne by the author.) 